\title{
'Green podiatry' - reducing our carbon footprints. Lessons from a sustainability panel
}

Angela Margaret Evans

\begin{abstract}
Background: The eyes of the world will be on COP26 as it meets in Glasgow in November, 2021. Our planet is displaying weather extremes due to climate change which cannot be ignored, and which are deleterious for people's health. Ironically, healthcare contributes to climate change, contributing approximately $5 \%$ of carbon emissions globally. Climate change due to global warming is 'the biggest global health threat of the 21st century'.

Main body: The Australian Podiatry Association conference held a sustainability panel, hearing perspectives of industry and science, medicine and sport, fashion, and retail. Content unified a broad planet and human health message, which is highly relevant for podiatrists. Key themes included waste as a resource, exercise as evidencebased intervention, responsibility and circular economy recycling principles for end-of-life product (footwear) purchases, and wider ethical considerations of footwear and clothing.

The Anthropocene origin of climate change requires humanity to collaborate and to live more sustainably. Innovation is essential for better energy modes, cleaner air, human health and earth care.

Green Podiatry joins the concerted activity of medical and health groups within Australia. The UK's NHS is an exemplar in this area, having already reduced healthcare emissions by 35\%, and aiming for net zero by 2045 , and perhaps sooner.
\end{abstract}

Conclusion: People are increasingly concerned about climate change, and COP26 is an important and imminent meeting for human and planet health.

This commentary on Green Podiatry directs us all to lighten our carbon footprint. A final, and forthcoming commentary will outline practical ways of positively incorporating climate change communication into the clinical setting.

Keywords: Climate change, Footprint, Healthcare, Carbon, Podiatry, Emissions, Health, Green

Correspondence: angela.evans@latrobe.edu.au

Discipline of Podiatry, School of Allied Health, Human Services and Sport, La

Trobe University, Melbourne, Victoria 3086, Australia

(c) The Author(s). 2021 Open Access This article is licensed under a Creative Commons Attribution 4.0 International License, which permits use, sharing, adaptation, distribution and reproduction in any medium or format, as long as you give appropriate credit to the original author(s) and the source, provide a link to the Creative Commons licence, and indicate if changes were made. The images or other third party material in this article are included in the article's Creative Commons licence, unless indicated otherwise in a credit line to the material. If material is not included in the article's Creative Commons licence and your intended use is not permitted by statutory regulation or exceeds the permitted use, you will need to obtain permission directly from the copyright holder. To view a copy of this licence, visit http://creativecommons.org/licenses/by/4.0/ The Creative Commons Public Domain Dedication waiver (http://creativecommons.org/publicdomain/zero/1.0/) applies to the data made available in this article, unless otherwise stated in a credit line to the data. 


\section{Background}

Health care's $(\mathrm{HC})$ carbon footprint is equivalent to $5 \%$ of global net emissions, and contributes to climate change [1].

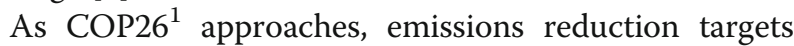
remain well behind in Australia, where $\mathrm{HC}$ emissions exceed 7\%. Hospitals contribute almost half [2], with energy use $60-70 \%$ of all $\mathrm{HC}$ emissions, mainly from fossil fuels.

'Health Care without Harm' is a principle that all health practitioners would, it is hoped, aspire to [3]. Hence, we must act to reduce health-harming climate change, from increased greenhouse gases, and the resulting effects, as recently (June - August 2021) seen in Germany (floods), Siberia (fires), polarised temperatures of 55C in Canada, and $18 \mathrm{C}$ in Antarctica $[4,5]$.

COP26 may be the last chance to agree on measures that could limit global warming to $1.5^{\circ} \mathrm{C}$. There is unique opportunity to align the global recovery from COVID-19, with the response to climate change to improve public health, create sustainable economies, and protect the planet [6].

\section{The sustainability panel}

The finale to the Australian Podiatry Association 2021 conference, attended online by over 800 delegates, saving tonnes of $\mathrm{CO}_{2}$ emissions, was a sustainability panel. This forum addressed sustainability from the perspectives of industry and science, medicine and sport, fashion, and retail, and united a 'no waste', and broad planet and human health message, with a complementary podcast [Additional file 1 - Link 1]. It was fascinating, and highly relevant for podiatrists. ${ }^{2}$

Scientia Professor Veena Sahajwalla [Director of the Centre for Sustainable Materials Research and Technology at University of New South Wales; Australian Research Council Laureate Professor]

- Waste is a resource: micro-resources and materials to be recycled, re-used, reformed at end of use to be fit for a new purpose as functional products, eg 'green steel' from old car tyres.

- Averting products from landfill, and manufacturing quality products from waste (within Australia) can realise environmental, social, and economic benefits simultaneously.

- A pilot collaboration into 'green foot orthoses' has begun.

\footnotetext{
${ }^{1}$ Conference of the Parties - meeting of the 197 members to the United Nations Framework Convention on Climate Change ${ }^{2}$ Sustainability panel recording: https://www.smart.unsw.edu.au/newsevents/news/podiatry-and-sustainability
}

Dr. John Orchard AM [Sport \& Exercise Physician; Adjunct Professor, Sydney School of Public Health]

- Exercise is demonstrated as effective treatment for most of Australia's National Health Priority Areas, viz. cardiovascular disease, cancer, arthritis, back pain, depression, osteoporosis, and diabetes [Additional file 1 - Link 2]

- Podiatrists need to consider exercise as first-line treatment, which is evidence based and valuable for every patient, ahead of foot orthoses [7]

- Is treatment even necessary [8]? If not necessary, or of low value, not evidence-based, and especially if also carbon emission 'heavy', it is wise to eliminate wasteful interventions, as these do not help patients, and harm the environment, eg

- customised foot orthoses for non-painful paediatric flatfeet [9-11], plantar heel pain [12]

- imaging for calcaneal apophysitis [13, 14]

- Health professionals need to drop non-evidencebased interventions, and choose wisely [Additional file 1 - Link 3].

Shaun Bajada [Executive Director, Australian Sporting Goods Association (ASGA)]

- Australians purchase more than 25 million pairs of sports shoes annually.

- ASGA's shoe recycle programme is called 'save our soles' (SOS). SOS has recycled more than 115,000 shoes, converting these to gym mats, flooring, playground turf.

- SOS operates as a circular economy, taking responsibility for end of life of purchased products. The principle is to be carbon neutral. ${ }^{3}$

- SOS notes that increasingly, sustainability is the cornerstone of the consumer's mind.

Nick Savaidis [Founder and Director, Etiko]

- The fashion industry is the second largest polluting industry after the oil industry [15].

- Etiko's long term goal is to keep its carbon footprint minimal

- Adopted a circular economy model, with a 'take back' program for old footwear

- Etiko address their total impact, considering workers, farmers in the supply chain - promoting ethical production, as well as environmental sustainability, as a Fair Trade Certified brand [Additional file 1 - Link 4].

${ }^{3}$ SOS collection depots: https://www.asgasosinitiative.com.au/ collection-locations/ 
Table 1 A suggested check-list for display in Green podiatry practices, and tips for home. Selecting whichever actions apply, simple Green Podiatry signage can start conversations about health and climate change with patients, and designate more sustainable clinics for consumers.

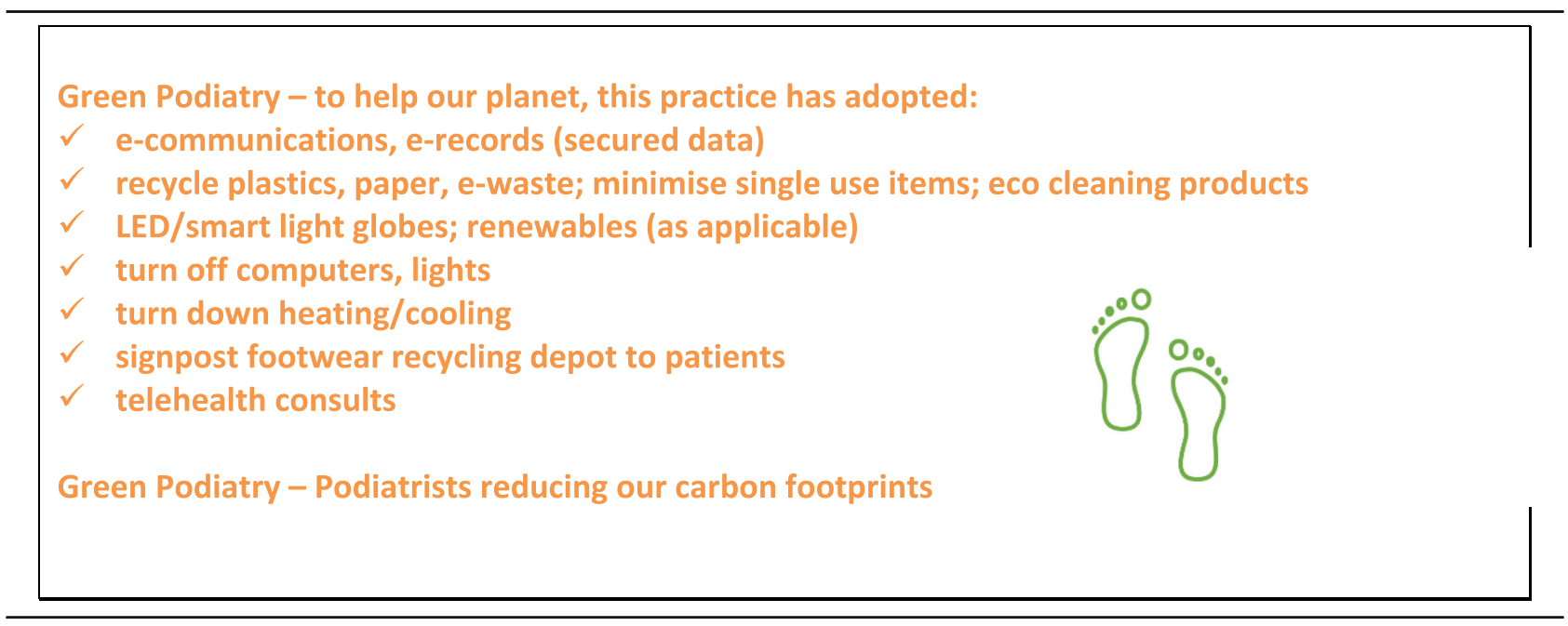

\section{Green podiatry can improve health}

The 2019 Australian Podiatry conference theme was 'Physical activity, Feet, and wider health'. In 2021, the virtual sequel theme, was 'Innovation and Collaboration'. Given the Anthropocene origin of climate change [5, 16], we need to collaborate to live more sustainably. Innovation is a big part of this, and drives developments in better energy use and earth care [17].

Podiatrists can make a Green $\mathbf{L E A P}$, and be actively involved in sustainable $\mathrm{HC}$ (Table 1):

- Lead on environmental sustainability

- Educate themselves about environmental sustainability

- Advocate for better healthcare sustainability

- Participate in environmentally sustainable workplaces [17].

\section{In the global context, it is 'all aboard'}

The 6th Assessment Report of the Intergovernmental Panel on Climate Change, 2021 has declared a Code Red for humanity [Additional file 1 - Link 5]. The Paris agreement, the United Nations, and the WHO all acknowledge the environmental impacts from $\mathrm{HC}$ from:

- consumption of energy and resources

- greenhouse gas emissions

- use/disposal of toxic chemicals

- production of waste/wastewater.

A time of global reckoning approaches with COP26 [Additional file 1 - Link 6].

\section{'Down under' - and all over}

Doctors for the Environment Australia (DEA) recognise that human health and wellbeing require an environment that is pollution-free, able to provide nutritious food, rich in biodiversity, and able to sustain current and future generations. DEA have adopted the mantra: 'healthy planet, healthy people' [Additional file 1 - Link 7].

The Climate and Health Alliance (CAHA) is a coalition of $\mathrm{HC}$ stakeholders, from medicine, nursing, public health, social work, and psychology, as well as HC service providers, research and academic institutions, and health consumers. CAHA have a guide for health professionals to act on climate change [Additional file 1 - Link 8]. The report, entitled Real, Urgent and Now, found that $86 \%$ of health professionals want immediate action on climate change [Additional file 1 - Link 9].

The Australian Podiatry Association has commenced a 'green' strategy [Additional file 1 - Link 10]. By applying the principle of responsible consumption and production, podiatrists can reduce emissions at work, and at home (Table 1). The promotion of healthy feet for walking, running, and cycling, enables carbon-neutral transport, and also benefits health.

The UK's NHS has led the world in developing a strategy for sustainability, with a Sustainable Development Unit (SDU) and carbon reduction targets [Additional file 1 Link 11]. The NHS is an exemplar, having cut its carbon footprint by $25 \%$ since 1990 , and by $35 \%$ since 2008 [1821], mostly by less reliance on fossil fuels, and decarbonising UK electricity. Air quality has improved, financial savings made, and $92 \%$ of NHS staff are supportive. ${ }^{4}$ Clinical

${ }^{4}$ Nick Watts, 14/9/2021, https://dea.org.au/event/australian-medicalassociation-doctors-for-the-environment-australia-webinar/ 
care is the next NHS challenge, as further carbon footprint reductions require clinical care to change. In some areas, opportunities for reuse are limited (eg infection control standards). This requires innovation, as do single use items [22], and avoiding unnecessary or low value care [Additional file 1 - Link 12]. The Royal College of Physicians have produced a guide for health professionals to reduce waste and the NHS target is to reduce carbon emissions by 80\%, by 2045 .

People are increasingly concerned about climate change, and more consumers prefer sustainable practices $[6,23]$. Podiatrists are in a great position to act and to educate [24]. Leadership needs passionate people to role model 'green' behaviours, and HC students are a vital inclusion, with many already concerned about their futures $[25,26]$.

\section{The environment cannot wait}

Eco-ethical leaders are needed in academia and $\mathrm{HC}$ to join environmental advocates and activists [24]. Using the WHO physical activity guidelines [7], underpins the importance of exercise for health, and to teach patients about exercise benefits for their health, as well as the planet.

\section{Conclusions}

"Climate change is the biggest global health threat of the 21st century" [27], yet with vision, has the potential to be, 'the greatest healthcare opportunity of the $21^{\text {st }}$ century' [Additional file 1 Link 13].

COP26 is pivotal for global warming to be reined in. Green Podiatry, as part of green HC, directs us all to lighten our carbon footprint. The next commentary will focus on talking with patients about green $\mathrm{HC}$, and the need to eliminate low value care, to promote exercise, sustainable footwear, and telehealth. This is important, as people are worried $[6,28]$.

\section{Abbreviations}

$\mathrm{CO}_{2}$ : carbon dioxide; WHO: World Health Organisation; UN: United Nations; DEA: Doctors for the Environment Australia; CAHA: Climate and Health Alliance; HC: Healthcare; COP26: Conference of Parties, Glasgow, November 2021; NHS: National Health Service

\section{Supplementary Information}

The online version contains supplementary material available at https://doi. org/10.1186/s13047-021-00497-1.

Additional file 1

Acknowledgements

N/A (references).
Conflicts of interest (real or perceived)

Director, Australian Podiatry Association.

Research Lead, Walk for Life, Bangladesh.

Chair, Sustainability Panel, APodA conference 2021.

\section{Disclaimer}

I am not a climate change expert, but an engaged earth-dweller, envisaging a podiatry (and whole of health care) community which can act to avert climate change, to better the health of our planet, and ourselves.

Author's contributions

AE conceived, wrote.

Funding

nil

Availability of data and materials

N/A

\section{Declarations}

Ethics approval and consent to participate

N/A

Consent for publication

implicit.

Competing interests

see below re $\mathrm{COI}$.

Received: 4 October 2021 Accepted: 31 October 2021

Published online: 29 November 2021

References

1. Watts N, Amann M, Arnell N, Ayeb-Karlsson S, Beagley J, Belesova K, et al. The 2020 report of the lancet countdown on health and climate change: responding to converging crises. Lancet. 2020;397(10269):129-70. https:// doi.org/10.1016/S0140-6736(20)32290-X.

2. Smith JA, Patrick R. The global climate and health agenda: Australia must do more. Health Promot J Aust. 2021;32(S2):3-4. https://doi.org/10.1002/ hpja.529.

3. Heilig S, Kushner T, Thomasma D. Health care without harm: an ethical imperative. Western J Med. 2001;175(4):222-3. https://doi.org/10.1136/ ewjm.175.4.222.

4. Atwoli L, Baqui AH, Benfield T, Bosurgi R, Godlee F, Hancocks S, et al. Call for emergency action to limit global temperature increases, restore biodiversity and protect health. BMJ Open. 2021;11:e056565. https://doi. org/10.9775/2021.UNGA.editorial.

5. Atwoli L, Baqui AH, Benfield T, Bosurgi R, Godlee F, Hancocks S, et al. Call for emergency action to limit global temperature increases, restore biodiversity, and protect health. Lancet. 2021;398(10304):939-41. https://doi. org/10.1016/s0140-6736(21)01915-2.

6. Health TLP. Mitigating climate change must be a priority for public health Lancet Public Heal. 2021;6(9):e620. https://doi.org/10.1016/S2468-2667(21 )00190-0.

7. Bull FC, Al-Ansari SS, Biddle S, Borodulin K, Buman MP, Cardon G, et al. World Health Organization 2020 guidelines on physical activity and sedentary behaviour. Brit J Sport Med. 2020;54(24):1451-62. https://doi.org/1 0.1136/bjsports-2020-102955.

8. Warner MA. Stop doing needless things! Saving healthcare resources during COVID-19 and beyond. J Gen Intern Med. 2020;35(7):2186-8. https://doi. org/10.1007/s11606-020-05863-6.

9. Evans AM, Rome K, Carroll M, Hawke F. Non-surgical interventions for paediatric flatfeet (pes planus). Cochrane Database of Systematic Reviews 2020; CD006311. doi:https://doi.org/10.1002\%2F14651858.CD006311.pub2.

10. Rome K, Ashford RL, Evans AM. Non-surgical interventions for paediatric pes planus. In: Non-surgical interventions for flat feet in children; 2011.

11. Evans $\mathrm{AM}$, Rome $\mathrm{K}$. A review of the evidence for non-surgical interventions for flexible pediatric flat feet. Eur J Phys Rehabil Med. 2011. 
12. Whittaker GA, Munteanu SE, Menz HB, Tan JM, Rabusin CL, Landorf KB. Foot orthoses for plantar heel pain: a systematic review and meta-analysis. Brit J Sport Med. 2018;52(5):322-8. https://doi.org/10.1136/bjsports-2016-097355.

13. Perhamre S, Lazowska D, Papageorgiou S, Lundin F, Klässbo M, Norlin R. Sever's injury. J Am Podiat Med Assn. 2013;103(5):361-8. https://doi.org/10. 7547/1030361.

14. Ramponi DR, Baker C. Sever's disease (calcaneal Apophysitis). Adv Emerg Nurs J. 2019:41(1):10-4. https://doi.org/10.1097/TME.0000000000000219.

15. Ramasamy R, Subramanian RB. Synthetic textile and microfiber pollution: a review on mitigation strategies. Environ Sci Pollut R. 2021;28(31):41596-611. https://doi.org/10.1007/s11356-021-14763-z.

16. Marshman J, Blay-Palmer A, Landman K. Anthropocene crisis: climate change, pollinators, and food security. Environ. 2019;6(2):22. https://doi.org/1 0.3390/environments6020022.

17. Evans AM. Sustainable healthcare - Time for 'Green Podiatry.' J Foot Ankle Res 2021; 14: 45, Sustainable healthcare - Time for 'Green Podiatry', 1, DOl: https://doi.org/10.1186/s13047-021-00483-7.

18. Roberts I. The NHS carbon reduction strategy. BMJ. 2009;338(jan28 1):b326. https://doi.org/10.1136/bmj.b326.

19. Watts N, Adger WN, Agnolucci P, Blackstock J, Byass P, Cai W, et al. Health and climate change: policy responses to protect public health. Lancet. 2015; 386(10006):1861-914. https://doi.org/10.1016/50140-6736(15)60854-6.

20. Tennison I, Roschnik S, Ashby B, Boyd R, Hamilton I, Oreszczyn T, et al. Health care's response to climate change: a carbon footprint assessment of the NHS in England. Lancet Planet Heal. 2021;5(2):e84-92. https://doi.org/1 0.1016/S2542-5196(20)30271-0.

21. Salas RN, Maibach E, Pencheon D, Watts N, Frumkin H. A pathway to net zero emissions for healthcare. BMJ. 2020;371:m3785. https://doi.org/10.1136/ bmj.m3785.

22. Pegna V, McNally SA. Are single use items the biggest scam of the century? Bulletin Royal Coll Surg Engl. 2021;103(5):233-5. https://doi.org/10.1308/ rcsbull.2021.89.

23. Wise J. Climate crisis: Over 200 health journals urge world leaders to tackle "catastrophic harm." BMJ 2021; 374: n2177, Climate crisis: Over 200 health journals urge world leaders to tackle "catastrophic harm", DOI: https://doi. org/10.1136/bmj.n2177.

24. McKimm J, McLean M. Rethinking health professions' education leadership: developing 'eco-ethical' leaders for a more sustainable world and future. Med Teach. 2020;42(8):1-6. https://doi.org/10.1080/0142159X.2020.1748877.

25. Hampshire K, Ndovu A, Bhambhvani H, Iverson N. Perspectives on climate change in medical school curricula-A survey of U.S. medical students. J Clim Change Heal 2021; 100033, 4, DOl: https://doi.org/10.1016/j.joclim.2 021.100033 .

26. Brand G, Collins J, Bedi G, Bonnamy J, Barbour L, llangakoon C, et al. "I teach it because it is the biggest threat to health": integrating sustainable healthcare into health professions education. Med Teach. 2020:1-9. https:// doi.org/10.2139/ssrn.3566173.

27. Watts N, Amann M, Arnell N, Ayeb-Karlsson S, Belesova K, Boykoff M, et al. The 2019 report of the lancet countdown on health and climate change: ensuring that the health of a child born today is not defined by a changing climate. Lancet. 2019;394(10211):1836-78. https://doi.org/10.1016/S0140-673 6(19)32596-6.

28. Brand G, Collins J, Bedi G, Bonnamy J, Barbour L, llangakoon C, et al. "I Teach It Because It Is the Biggest Threat to Health": Integrating a Planetary Health Perspective into Health Professions Education. Ssrn Electron J. 2020. https://doi.org/10.2139/ssrn.3566173.

\section{Publisher's Note}

Springer Nature remains neutral with regard to jurisdictional claims in published maps and institutional affiliations.

Ready to submit your research? Choose BMC and benefit from:

- fast, convenient online submission

- thorough peer review by experienced researchers in your field

- rapid publication on acceptance

- support for research data, including large and complex data types

- gold Open Access which fosters wider collaboration and increased citations

- maximum visibility for your research: over $100 \mathrm{M}$ website views per year

At $\mathrm{BMC}$, research is always in progress.

Learn more biomedcentral.com/submissions 